\title{
PEMBERDAYAAN EKONOMI MASYARAKAT MELALUI EDUKASI INVESTASI DI PASAR MODAL SESUAI FATWA MUI No. 80 BAGI PENGURUS MASJID KOTA DEPOK
}

\author{
Sabar Warsini ${ }^{1 凶}$, Ali Masjono ${ }^{2}$, Petrus HKS ${ }^{3}$ Fatimah $^{4}$, Indianik Aminah ${ }^{5}$ \\ 1,2,3,4,5 Politeknik Negeri Jakarta \\ Jl. Prof. Dr. GA Siwabessy, Kampus UI Depok, 16425, Telp (021-7863537) \\ $\otimes_{e-m a i l:}$ Isabar.warsini@akuntansi.pni.ac.id
}

\begin{abstract}
Fatwa of Majelis Ulama Indonesia No 80/DSN-MUI/III/2011 about sharia capital market, should be told to the general public that society understand about sharia investment. Galery Investasi PNJ have significant roles in educate people that understand why investment in accordance sharia truth and Islamic. Program study of D4 Financial Management PNJ have competence in the field of capital market, have an obligation to do an activity education about sharia investment through the Community Social Activity to the mosque management in Depok City. Objectives of the Community Social Activity is to increase community understanding about the truth and the importance of investment in accordance with the islamic sharia so that community can be avoided from fraud investment. Method is carried out by providing lectures education by expert sharia capital market do accompanied by a trading use application MNC-trade. This Community Social Activity done in cooperation with MUI Depok
\end{abstract}

Keywords: Fatwa of MUI No. 80, investment, sharia capital market, management of mosque

\begin{abstract}
Abstrak
Fatwa MUI No 80 tentang pasar modal syariah perlu disosialisasikan kepada masyarakat luar karena fatwa ini tidak ada artinya jika masyarakat belum memahaminya. Galery Investasi yang dimiliki PNJ sangat berperan dalam mendidik masyarakat agar paham bagaimana berinvestasi yang benar dan sesuai dengan syariah Islam. Sesuai dengan kompetensinya Prodi D4 Manajemen Kuangan PNJ melakukan kegiatan PkM dengan memberikan edukasi investasi syariah sesuai Fatwa MUI No 80 kepada masyarakat sekitar yaitu pengurus masjid kota Depok. Tujuan kegiatan PkM ini adalah untuk meningkatkan pemahaman masyarakat akan pentingnya investasi yang benar dan sesuai dengan ketentuan syariah islam sehingga masyarakat tidak terjebak pada investasi bodong yang pernah menimpa masyarakat kota Depok. Metode edukasi dilakukan dengan memberikan ceramah oleh pakar pasar modal syariah disertai dengan simulasi melakukan trading menggunakan aplikasi MNC trade. Kegiatan PkM ini terlaksana berkat kerja sama dengan MUI Kota Depok dan MNC Sekuritas. Peserta pelatihan sebanyak 40 pengurus masjid di Kota Depok.
\end{abstract}

Kata kunci: Fatwa MUI No 80, investasi, pasar modal syariah, pengurus masjid

\section{Pendahuluan}

\section{Latar Belakang}

Berdasarkan hasil kegitan pengabdian masyarakat Prodi D4 Manajemen Keuangan PNJ yang dilakukan 3 tahun terakhir sejak 2016 menemukan bukti bahwa investasi melalui pasar modal masih belum mendapat tempat dihati masyarakat, khususnya masyarakat muslim kota Depok. Bahkan tidak sedikit masyarakat beranggapan bahwa bermain saham adalah berjudi sehingga dinilai haram. Masyarakat lebih memahami Deposito, Emas, Property dan bewirausaha sebagai sarana berinvestasi. Hal ini disebabkan karena kurangnya pemahaman masyarakat tentang pasar modal. Sementara bagi pelaku pasar modal yang telah ahli dan berpengalaman, pasar modal merupakan tempat yang paling ideal untuk berinvestasi karena tingkat likuiditasnya yang tinggi dan tidak memerlukan dana investasi yang besar seperti ketika berinvestasi di properti atau asset riil lainnya.

Dukungan untuk berinvestasi di pasar modal bertambah kuat sejak Majelis Ulama Indonesia mengeluarkan Fatwa MUI Nomor 80/DSN-MUI/III/2011 tentang Penerapan 
Prinsip Syariah di Bidang Pasar Modal. Dikeluarkannya fatwa MUI ini menambah keyakinan bahwa investasi dipasar modal tidak melanggar tatanan/syariah agama Islam. Oleh karena itu PNJ sebagai salah satu perguruan tinggi di Kota Depok mempunyai kewajiban dan tanggung jawab untuk mengedukasi masyarakat sekitarnya tentang investasi yang benar sesuai dengan syariat Islam seperti yang diatur dalam Fatwa MUI No 80 tersebut, sehingga masyarakat tidak terjebak pada investasi bodong, Investasi dengan Skema Ponzi seperti kasus Koperasi Simpan Pinjam (KSP) Pandawa Mandiri Group yang telah banyak menimbulkan kerugian bagi masyarakat Depok.

Skema Ponzi adalah modus investasi palsu yang membayarkan keuntungan kepada investor dari uang mereka sendiri atau uang yang dibayarkan oleh investor berikutnya, bukan dari keuntungan yang diperoleh oleh individu atau organisasi yang menjalankan operasi ini. Skema Ponzi sangat menyesatkan, karena itu Ketua MUI Kota Depok, KH Ahmad Dimyati Badruzaman memutuskan bahwa KSP Pandawa Mandiri Group haram karena ada unsur praktek riba. Hal ini ditegaskan dalam surat Keputusan Fatwa MUI Kota Depok Nomor 01/SK/MUI/Dpk/VI/2016, bahwa KSP Pandawa Mandiri merupakan koperasi yang berkedok pengelola dana investasi yang melakukan prakteknya dengan mencatut pemuka agama Islam. (Ningsih, A. 2016, June 23)

Berdasarkan analisis situasi tersebut maka sangat penting bagi Program Studi D4 Manajemen Keuangan untuk melakukan kegiatan pengabdian kepada masyarakat Kota Depok untuk memberikan edukasi investasi. Kegiatan ini sesuai dengan kompetensi program studi, didukung dengan keberadaan Galeri Investasi dan tenaga dosen yang telah memiliki sertifikat kompetensi di bidang pasar modal.

\section{Permasalahan}

Masyarakat mempunyai potensi yang besar untuk melakukan investasi dengan dana yang dimiliki. Tetapi masih rendahnya pemahaman masyarakat tentang investasi yang benar menyebabkan banyaknya masyarakat yang menjadi korban investasi bodong hanya tergiur dengan dijanjikannya untung yang besar dan cepat. Perkembangan berbagai instrument investasi yang dikeluarkan di pasar modal merupakan peluang yang besar bagi masyarakat untuk memperoleh penghasilan investasi. Akan tetapi karena masih banyak masyarakat khususnya umat Islam yang beranggapan bahwa investasi saham adalah judi (haram) sehingga ada keengganan masyarakat untuk mengenal pasar modal. Untuk mengatasi permasalahan tersebut maka perlu adanya edukasi dan sosialisasi kepada masyarakat tentang Fatwa MUI No 80 sebagai landasan umat Islam dalam berinvestasi di pasar modal.

\section{Tujuan}

Tujuan yang ingin dicapai dengan dilaksanakan kegiatan pengabdian masyarakat ini adalah: (1). Memberikan edukasi investasi yang benar, (2). Mengenalkan pasar modal syariah sesuai Fatwa MUI No 80, (3). Mengenalkan Galeri Investasi PNJ kepada masyarakat umum, dan (4). Memberdayakan ekonomi masyarakat sekitar kampus melalui kegiatan investasi.

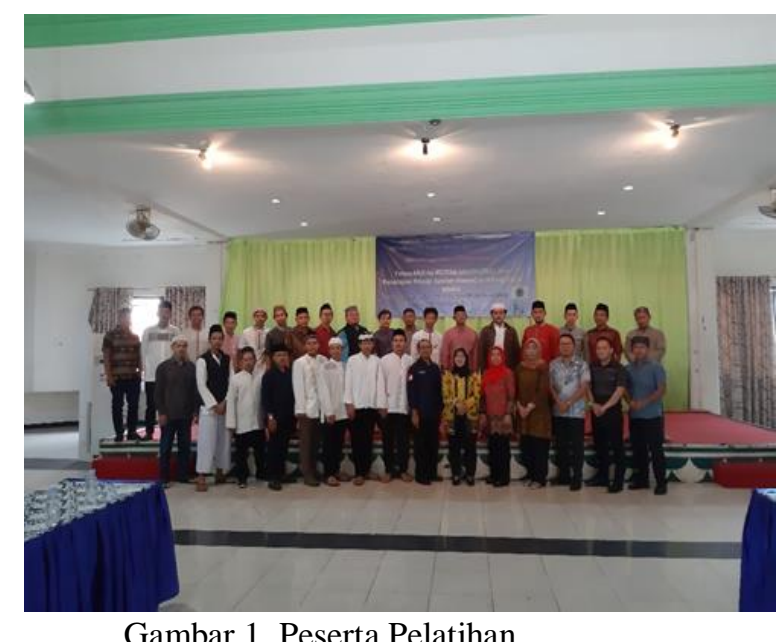

\section{Solusi yang ditawarkan}

Untuk mengatasi permasalahan yang ada maka solusi yang ditawarkan dalam kegiatan pengabdian masyarakat ini adalah: 
1. Mengedukasi masyarakat tentang investasi yang baik, benar dan sesuai syariah. Pendidikan akan diadakan di lokasi komunitas masyarakat (Kantor MUI Depok) masing masing dengan nara sumber dari PNJ dan MNC Securitas (ada MOU). Komunitas masyarakat yang dipilih adalah 40 orang pegurus masjid di Kota Depok. Edukasi berupa pelatihan dan simulasi trading saham menggunakan aplikasi $M N C$-trade.

2. Melakukan pendampingan bagi peserta untuk melakukan, simulasi investasi selama 3 bulan pertama setelah pelatihan, selanjutnya setelah mahir dengan simulasi, maka akan dihubungkan dengan perusahaan MNC Sekuritas guna menyalurkan minat berinvestasi. Dari 40 orang peserta diharapkan ada $10 \%$ yang mau belajar lebih lanjut berinvestasi secara simulasi di Galeri Investasi PNJ.

3. Pemantauan dilakukan kepada peserta yang melakukan simulasi secara online dan memberikan nasehat jika mengalami kendala.

\section{Metode Pengabdian}

Metode pelaksanaan kegiatan Pengabdian kepada Masyarakat ini mencakup beberapa tahapan yang dapat digambarkan sebagai brikut:

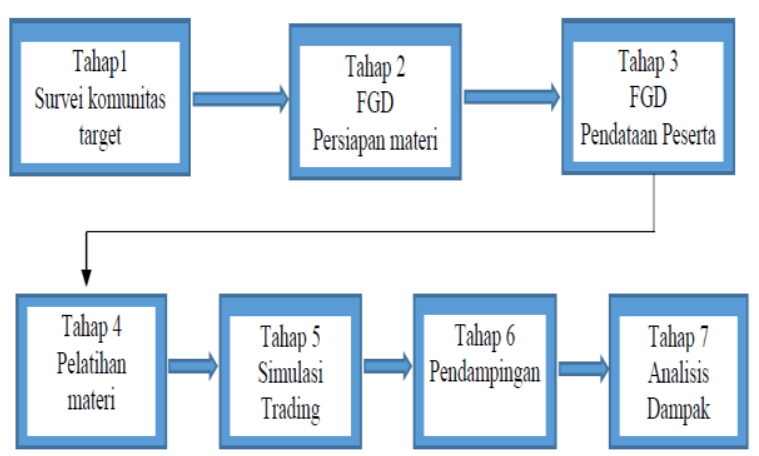

Gambar2. Tahapan kegiatan PkM

\section{Tahap survey}

Melakukan pendekatan kepada komunitas yang dijadikan target pelatihan, dalam kegiatan ini adalah melakukan pendekatan dan konsultasi dengan MUI Kota Depok dan pengurus masjid.
2. Tahap FGD Materi

Pada kegiatan FGD ini dilakukan untuk menetapan materi pelatihan yang akan disampaikan kepada peserta. FGD ini dilakukan oleh dosen homebase Prodi D4 Manajemen Keuangan dengan melibatkan pihak MNC Securitas sebagai narasumber pelatihan

3. Tahap FGD Penentuan peserta

Tahap FGD ini dilakukan dengan pengurus MUI Kota Depok untuk menentuakn siapa peserta yang tepat untuk mengikuti pelatihan investasi syariah. Sesuai arahan dari MUI maka ditetapkan peserta pelatihan adalah pengurus masjid Kota Depok. Hal ini sesuai dengan peran masjid dalam mengayomi masyarakat. Alasannya adalah bahwa jika pengurus masjid memahami cara berinvestasi yang baik dan benar maka ilmu tersebut akan menular kepada masyarakat banyak, sehingga korban dari investasi bodong dapat diminimalisir

4. Tahap pelatihan

Tahap pelatihan dibagi menjadi 2 sesi. Pada sesi pertama peserta diberikan pelatihan tentang pentingnya perencanaan keuangan. Pelatihan perencanaan keuangan ini menjadi dasar dilakukannya kegiatan investasi. Selanjutnya pada sesi 2 pelatihan yang diberikan adalah focus investasi syariah dengan didahului dengan pengenalan pasar modal syariah dan hukum investasi syariah.

5. Tahap simulai trading

Setelah peserta diberikan pelatihan dengan cara penyuluhan tentang perencanaan keuangan dan investasi syariah maka tahap selanjutnya peserta diajak untuk melakukan simulasi trading saham syariah dengan menggunakan aplikasi $M N C$ trade. Kepada setiap peserta diberikan aplikasi dengan cara diinstall di hand phone peserta sehingga peserta dapat melakukan praktik trading secara real time.

6. Tahap Pendampingan

Aplikasi $M N C$-trade dapat digunakan untuk simulasi selama 3 bulan. Selama 3 bulan peserta memperoleh pendampingan 
oleh mahasiswa prodi Manajemen Keuangan. Pendampingan dan pemantauan dilakukan secara online. Pendampingan juga digunakan untuk memberikan solusi ketika peserta menemui kendala.

7. Tahap Analisis Dampak

Dengan menggunakan aplikasi $M N C$ trade selama 3 bulan diharapkan peserta telah mempunyai kemampuan trading saham yang cukup sehingga tahap selanjutnya peserta bisa melakukan investasi secara riil. Ketika pengurus masjid telah memahami cara investasi yang benar sesuai syariah islam diharapkan dapat menularkan ilmunya dan memberikan edukasi kepada masyarakat sekitar sehingga dalam jangka panjang akan berdampak pada peningkatan kesejahteraan masyarakat.

\section{Hasil Dan Pembahasan}

Sesuai dengan perencanaan, pelaksanaan kegiatan PkM Program Studi D4 Manajemen Keuangan PNJ tahun 2019 mengambil tema Pemberdayaan Masyarakat Melalui Sosialisasi Pasar Modal Syariah pada pengurus Masjid Kota Depok. Secara spesifik bentuk kegiatanya adalah "Sosialisasi Fatwa MUI No80/DSNMUI/III/2011 tentang Penerapan Prinsip Syariah di Bidang Pasar Modal". Metode yang diterapkan sesuai dengan metode pendidikan politeknik yakni pelatihan diberikan secara teori dan praktik.

Kegiatan ini dilaksanakan pada tanggal 18 September 2019 bertempat di Gedung Pertemuan Kantor MUI Kota Depok, Jl. Nusantara Depok mulai dari pukul 08.00 sampai dengan pukul 16.30 WIB. Kegiatan ini diikuti oleh 60 personal.

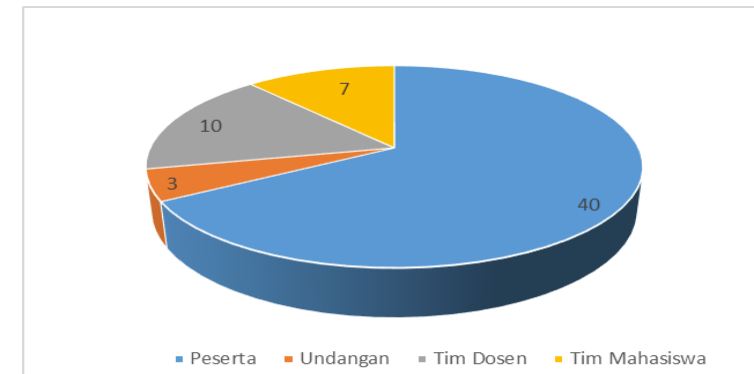

Gambar 3. Peserta kegiatan PkM Prodi MK

Kegiatan diawali dengan tilawah Alqur'an oleh mahasiswa yang bertugas. Selanjutnya secara resmi kegiatan PkM Prodi D4 Manajemen Keuangan PNJ dibuka oleh Dr. Ida Nurhayati, SH,.MH selaku Kepala P3M PNJ. Setelah secara resmi kegiatan dibuka maka Ketua MUI Kota Depok, KH Ahmad Dimyati Badruzaman memberikan sambutan yang pada intinya adalah mengingatkan pentingnya mengelola keuangan dan menjelaskan prinsip investasi dalam ajaran agama Islam. Ketua MUI Kota Depok dalam sambutannya juga berharap bahwa kegiatan ini dapat dimanfaatkan sebaik baiknya oleh peserta yang terdiri dari pengurus masjid sehingga peran masjid sebagai pusat informasi dan pemberdayaan ekonomi masyarakat dapat terwujud.

Pelatihan sesi pertama dimulai dengan memberikan penyuluhan pentingnya membuat perencanaan keuangan keluarga yang disampaikan oleh nara sumber Fathir Ashfath, SE, MM. Secara menarik narasumber memaparkan berbagai komponen terkait perencanaan keuangan keluarga yaitu:

1. Apa makna perencanaan keuangan

2. Mengapa membuat perencanaan keluarga itu penting

3. Apa akibatnya jika tidak ada perencanaan keuangan

4. Bagaimana langkah-langkah membuat perencanaan keuangan

5. Alternative sarana investasi apa saja yang dapat dimasukan dalam perencanaan keuangan

Penyampaian materi perencanaan keuangan keluarga disampaikan oleh narasumber dengan sangat menarik sehingga diikuti dengan sangat antusias oleh peserta. 
Antusiasme peserta dapat dilihat dari banyaknya pertanyaan peserta yang diajukan disela-sela narasumber memberikan penjelasan. Dari pertanyaan yang diajukan dapat diindikasikan bahwa sebagian besar peserta masih belum memahami pentingnya membuat perencanaan keuangan keluarga, belum pernah membuat perencanaan keuangan meskipun secara sederhana, belum memahami bagaimana investasi yang benar. Berbagai pertanyaan yang diajukan oleh peserta dapat dijawab dan dijelaskan dengan baik oleh narasumber.

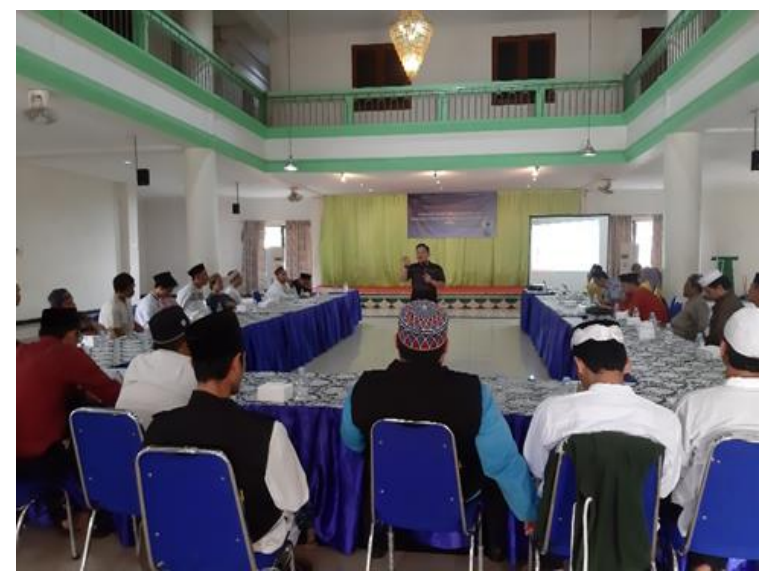

Gambar 4.Pelatihan perencanaan keuangan

Narasumber menyampaikan materi dengan jelas, memberikan contoh pada penerapan sehari-hari sehingga mendapat sambutan baik oleh peserta dengan adanya beberapa pertanyaan pada sesi tanya jawab. Dari sesi tanya jawab menunjukkan bahwa sebagian besar peserta belum pernah melakukan atau membuat perencanaan keuangan. Peserta juga menyampaikan bahwa selama ini alternative investasi yang telah mereka lakukan adalah menabung dan membeli emas perhiasan.

Pada sesi kedua dengan narasumber bapak Sutrisna Atmaja praktisi dari MNC Securitas menyampaian materi yang menjelaskan tentang pasar modal syariah. Pada prinsipnya pasar modal syariah secara mekanisme sama dengan pasar modal konvensional. Yang berbeda adalah ahad dan produknya. Materi yang disampaikan mencakup:

1. Tinjauan investasi menurut syariat islam 2. Dasar Hukum Investasi Syariah
3. Produk-produk investasi syariah

4. Kiat memilih produk investasi

Pemaparan diakhiri dengan sesi tanya jawab. Beberapa peserta meminta penjelasan secara lebih detail apakah investasi di saham itu tidak haram. Peserta lain menyatakan bahwa investasi saham itu masih sangat rumit, sehingga narasumber menjelaskan bahwa setelah sesi ini aka nada pelatihan simulasi trading menggunakan aplikasi virtual trading yang dikeluarkan oleh MNC Securitas, sehingga peserta dapat mencoba secara riil bagaimana cara investasi di saham, rumit atau tidak.

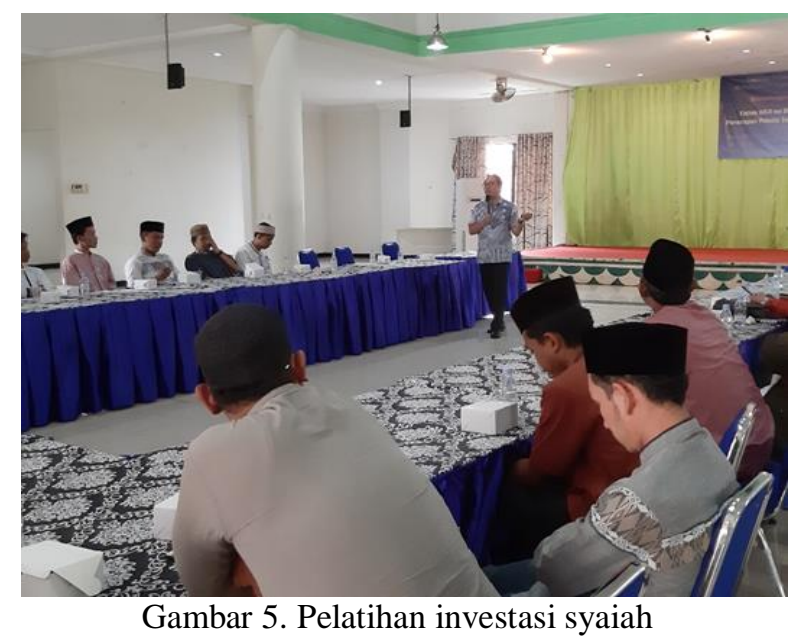

Di akhir sesi peserta diajak untuk simulasi penggunaan aplikasi virtual trading dari MNC Securitas untuk praktik melakukan investasi saham. Aplikasi MNC-trade diinstall ke hand phone peserta sehingga peserta dengan mudah bisa menggunakan aplikasi tersebut untuk simulasi. Akan tetapi hanya sebagian kecil dari peserta yang antusias dengan penggunaan aplikasi trading ini. Install aplikasi dan penggunaannya dibantu oleh mahasiswa prodi Manajemen Keuangan. Mahasiswa yang menjadi pendamping adalah mahasiswa semester 5 dimana mahasiswa tersebut telah menempuh mata kuliah praktik pasar modal dan sebagian telah menjadi investor. 


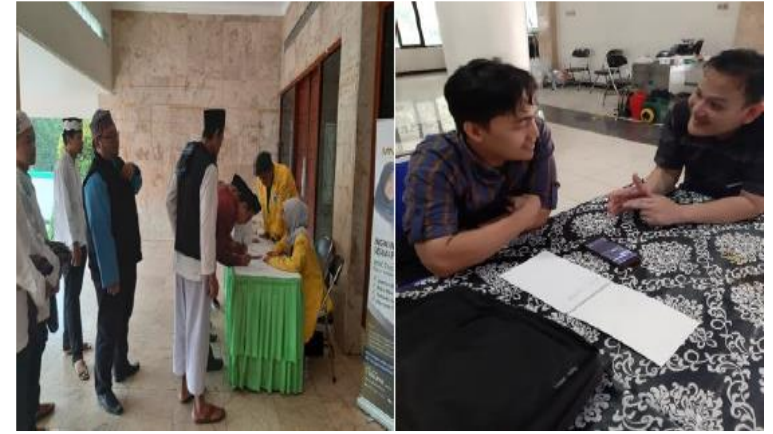

Gambar 6. Mendaftar aplikasi MNC-trade

Berdasarkan pelaksanaan kegaitan pengabdian selama tiga tahun terakhir tampak adalah wajar jika masyarakat pada umumnya termakan rayuan untuk berinvestasi dengan iming iming yang besar, faktor penyebab utama adalah tidak ada sosialisasi tentang cara berinvestasi yang baik dan benar serta sesuai syariah dan investasi di pasar modal tidak gampang danpenuh resiko. Salah satu peserta, menurut dugaan panitia mungkin terlibat dengan kegiatan koperasi pandawa, mengatakan bahwa mengapa sosialisasi tentang cara berinvestasi yang baik dan benar baru sekarang dilaksanakan.

Berkaca dari kasus investasi bodong yang yang marak terjadi di Indonesia dan koperasi Pandawa kota Depok, menjadi salah satu phenomena investasi bodong yang patut diwaspadai. Koperasi Pandawa yang dikota Depok termasuk model perusahaan investasi bodong yang merugikan masyarakat. Dari berbagai berita di koran kota Depok, terindikasi bahwa banyak masyarakata Kota Depok menjadi korban.

Di kota Depok, banyak sekali korban dari koperasi Pandawa, Dari berbagai informasi diketahui bahwa bukan saja masyarakat Kelurahan Meruyung (pusat Koperasi Pandawa) yang menjadi korban, salah satu kelurahan yang berdekatan dengan Kelurahan Meruyung adalah kelurahan Pasir putih dan kelurahan lainnya di sekitar Meruyung.

Dari pelaksanaan kegiatan $\mathrm{PkM}$ prodi Manajemen Keuangan tahun 2019, timbul pertanyaan mengapa tim pengabdian memilih pengurus Masjid? Untuk dijadikan sasaran sosialisasi pasar modal. Alasannya adalah bahwa jika pengurus Masjid memahami cara berinvestasi yang baik dan benar maka ilmu tersebut akan menular kepada masyarakat banyak, sehingga korban dari investasi bodong dapat diminimalisir. Hal ini terkait dengan peran masjid untuk mengayomi masyarakat dari investasi bodong.

Dari hasil kegiatan PkM tahun 2019 terindikasi bahwa pengetahuan pengurus masjid tentang pasar modal masih sangat rendah dan dapat dikatakan nol.

Melalui kegiatan pengabdian masyarakat ini tidak serta merta dapat meningkatkan investor di pasar modal. Yang paling utama adalah memberikan edukasi kepada masyarakat tentang investasi yang benar dan sesuai syariah islam. Hal ini disebabkan karena pengetahuan masyarakat sangat minim sehingga memerlukan usaha yang sangat besar agar masyarakat dapat memahami pasar modal. Image dimasyarakat tentang pasar modal sangat jelek, sebagian besar masih mengganggap sebagai judi, walaupun sudah di katakana bukan sebagai judi oleh MUI (Fatwa MUI no 80).

Jika selama ini sasarannya tidak terkontrol dan tidak tekendali, terutama tingkat pendidikan mereka, maka untuk tahun mendatang perlu disaring dengan berbagai metode, misalnya yang masyarakat ssasaran hanya berpendidikan miniml D3 atau S1 mereka yang menganggur, atau sedang menunggu pekerjaan.

Tantangan bagi pelaksana adalah bagaimana mendapatkan peserta sesuai dengan kriteria diatas, bagaimana mencari mereka atau mau belajar pasar modal. Kendala lain adalah kebijakan dari P3M yang tidak membolehkan kegiatan pengabdian kepada masyakarat di kampus. Sedangkan kegitan prodi MK ini sangat sesuai jika dilaksanakan di kampus dan dapat dilaksanakan secara terus menerus sepanjang tahun

Dari beberapa target luaran yang direncanakan seperti tercantum pada proposal, maka setelah pelaksanaan kegiatan PkM Prodi D4 Manajemen Keuangan PNJ target luaran yang telah dicapai adalah sebagai berikut: 
1. Publikasi ilmiah di jurnal/prosiding

Publikasi artikel melalui jurnal Mitra Akademia ini adalah salah satu upaya untuk men-deseminasikan hasil kegiatan pengabdian masyarakat prodi di lingkungan PNJ.

2. Publikasi pada media masa (cetak/elektronik). Pelaksanaan kegiatan PkM Prodi D4 Manajemen Keuangan telah dipublikasikan pada media masa elektronik melalui link berikut:

http://swarapendidikan.co.id/pnjgandeng-mui-sosialisasi-penerapanprinsip-syariah-di-pasar-modal/

3. Peningkatan pemahaman dan ketrampilan masyarakat

Hasil dari pelaksanaan kegiatan PkM Prodi D4 Manajemen Keuangan adalah adanya peningkatan pemahaman dan ketrampilan masyarakat khususnya peserta pelatihan yakni pemahaman mengenai pentingnya perencanaan keuangan dan pemahaman investasi yang berbasis syariah islam.

4. Peningkatan kualitas kehidupan keluarga dan pemberdayaan ekonomi masyarakat Dengan diberikan edukasi mengenai perencanaan keuangan dan investasi syariah kepada peserta khususnya pengurus masjid Kota Depok dengan cara penyuluhan dan praktik, maka diharapkan peserta tersebut mampu menerapkan dalam kehidupan keluarganya dan selanjutnya diharapkan akan secara berantai bisa memberikan edukasi kepada masyarakat dilingkungan masing-masing melalui peran masjid sebagai pusat informasi dan ekonomi, sehingga masyarakat teredukasi dengan benar tentang perencanaan keuangan dan investasi syariah yang pada akhirnya mampu menciptakan peningkatan kualitas kehidupan keluarga dan pemberdayaan ekonomi masyarakat

\section{Kesimpulan}

Berdasarkan pelaksanaan kegiatan PkM Prodi D4 Manajemen Keuangan dapat disimpulkan sebagai berikut: (a). Belum ada upaya meng-edukasi masyarakat secara meluas tentang investasi yang benar sehingga banyak masyarakat yang menjadi korban penipuan investasi bodong hanya karena tergiur oleh iming-iming keuntungan yang besar meskipun secara logika tidak masuk akal, (b). Pelasanaan kegiatan pengabdian kepada masyarakat selama ini masih belum memberikan manfaat kepada masyarakat sasaran yang telah dilatih dilihat dari masih rendahnya respon peserta terhadap minat berinvesati di pasar modal, (c). Masyarakat masih ada keraguan meskipun secara hukum MUI telah mengeluarkan fatwa bahwa investasi saham adalah tidak haram berdasarkan Fatwa MUI No. 80/DSNMUI/III/2011 tentang Penerapan Prinsip Syariah di Bidang Pasar Modal.

\section{Ucapan Terima Kasih}

Kegiatan pengabdian masyarakat prodi D4 Manajemen Keuangan PNJ ini dapat terlasana dengan baik berkat adanya dukungan dan bantuan dari beberapa pihak. Oleh karena itu kami tim prodi MK PNJ mengucapkan terima kasih kepada: (1) UP3M PNJ yang telah memberikan dukungan dan pendanaan untuk kegiatan PkM ini, (2). Pengurus MUI Kota Depok yang telah bekerjasama atas terselenggaranya kegiatan $\mathrm{PkM}$ ini mulai dari konsultasi persiapan hingga pelaksanaan, (3). Peserta pelatihan yakni 40 orang pengurus masjid di Kota Depok yang telah bersedia dan berkomitmen mengikuti kegiatan pelatihan sehinga diharapkan dapat menularkan ilmunya kepada masyarakat di sekitarnya.

\section{Daftar Pustaka}

[1] MUI, 2011. Fatwa Nomor: 80/DSNMUI/III/2011 tentang: Penerapan Prinsip Syariah dalam Mekanisme Perdagangan Efek bersifat Ekuitas di Pasar Reguler Bursa Efek.

[2] P3M PNJ, 2019. Panduan Pelaksanaan Penelitian dan Pengabdian Kepada Masyarakat Edisi XII.

[3] PNJ, 2019. Renstra P3M Politeknik Negeri Jakarta 2019-2024

[4] Sabar Warsini, dkk., 2019. Laporan Kegiatan Pengabdian Masyarakat Prodi 
D4 Manajemen Keuangan PNJ tahun 2019.

[5] https://www.liputan6.com/bisnis/read/39 52217/hati-hati-ini-daftar-73-investasibodong-yang-dilarang-ojk, 2019. Hati-
Hati! Ini Daftar 73 Investasi Bodong yang Dilarang OJK. Dipetik October Wednesday, 2019, dari Liputan6.com: (Puranidhi, A.L.) 